\title{
Use of Saltmarsh by Dragonflies (Odonata) in the Baie des Chaleurs Region of Quebec and New Brunswick in Late Summer and Autumn
}

\author{
Paul M. Catling ${ }^{1}$, Raymond Hutchinson ${ }^{2}$, and Paul M. Brunelle ${ }^{3}$ \\ ${ }^{1} 170$ Sanford Avenue, Ottawa, Ontario K2C 0E9 Canada; e-mail: catlinp@agr.gc.ca \\ 212 Ch. de la Savane, Appartment 12, Gatineau, Québec J8T 1P7 Canada; e-mail: Raymond.hutchinson@sympatico.ca \\ 34 Hilltop Terrace, Dartmouth, Nova Scotia B2Y 3T1 Canada; e-mail: pmb@ns.sympatico.ca
}

Catling, Paul M., Raymond Hutchinson, and Paul M. Brunelle. 2006. Use of saltmarsh by dragonflies (Odonata) in the Baie des Chaleurs region of Quebec and New Brunswick in late summer and autumn. Canadian Field-Naturalist 120(4): $413-420$

During late summer and autumn, in the Baie des Chaleurs region of Quebec, 18 species of adult dragonflies were recorded during one or more visits of at least 2 hours each to 14 saltmarshes. Three species, Aeshna canadensis, Sympetrum danae and $S$. internum, were present in more than half of the sites. The most abundant species was $S$. internum with over 100 seen at some locations. Adults of several species, including Aeshna canadensis, A. umbrosa, Enallagma civile, E. hageni, Ischnura verticalis, Lestes disjunctus, Libellula quadrimaculata, Sympetrum danae, S. internum and S. obtrusum, occurred in relatively high frequencies in both Baie des Chaleurs saltmarshes and in those elsewhere in Acadia. Within Baie des Chaleurs observations of emergence and/or presence of larvae, as well as regional abundance, were recorded for Aeshna canadensis, A. umbrosa, Ischnura verticalis, Sympetrum costiferum, S. internum and S. vicinum. Oviposition in saltmarsh pools was recorded for Aeshna canadensis, Enallagma civile, E, hageni, Ischnura verticalis, Lestes congener and Sympetrum danae. The saltmarsh dragonfly fauna of Baie des Chaleurs is significantly different from that of the rest of Acadia based on frequencies predicted from the latter region. To a large extent this difference is a result of significantly increased use of saltmarsh habitat by adults of six species including Lestes congener, Sympetrum danae, Aeshna canadensis, Sympetrum costiferum, Lestes disjunctus, and Sympetrum internum (in order of decreasing significance) in Baie des Chaleurs in comparison with saltmarshes elsewhere in Acadia. Local amelioration of salty conditions in certain saltmarshes, superimposed on regional amelioration as a result of protection from storms and saltwater dilution in the Baie des Chaleurs estuary, may contribute to an environment where adaptation can occur or where already tolerant species can exist. Dragonflies use saltmarsh habitat on the northeast coast of North America more extensively than is currently documented.

Key Words: Odonata, dragonflies, saltmarsh, Baie des Chaleurs, Quebec, New Brunswick.

Dragonflies are generally not highlighted as a group of insects that inhabits saltmarshes (e.g. Cheng 1976). Foster and Treherne (1976) outline the difficulty of characterizing marine insects because many species wander in from adjacent habitats. They define marine insects as having a "habitual requirement for some part of the saltmarsh environment at some stage of their life cycle." They show Odonata species comprising 3\% of saltmarsh insect fauna which is dominated by Diptera, Coleoptera and Hemiptera which collectively make up $75 \%$ of the species. Corbet (1999, page194) notes the only truly marine dragonfly is Erythrodiplax berenice, but that there is also a "heterogenous assemblage of Zygoptera and Anisoptera that occupy brackish waters, usually of relatively low salinity compared with seawater."

Dragonflies have been reported to prey on saltmarsh tabanid flies and mosquitos, both groups of aggressive biting insects that interfere with human activities. As a consequence, questions periodically arise as to the extent of use of saltmarsh by dragonflies. Very little information on this subject is available for the maritime region of eastern Canada. Hutchinson and Bélanger $(1999,2004)$ have reported on adults of Sympetrum danae and Enallagma civile (respectively) using saltmarsh in the Baie des Chaleurs region. These observations suggest that use of saltmarsh by dragonflies may be more extensive than suspected. Preliminary observations in the Baie des Chaleurs region of Quebec and New Brunswick supported this view and suggested the use of saltmarsh by widespread species of dragonflies.

The objective of the work reported here was to summarize information on the late summer and fall use of saltmarsh by dragonflies in this region and to provide a basis for further analysis of evolutionary and ecological aspects of occurrence.

\section{Methods}

The study area - Baie des Chaleurs

Baie des Chaleurs is bounded on the north by the Gaspé Peninsula and on the south by northern New Brunswick (Figure 1). Flowing into it at its far western end is the Restigouche River, famous for fishing of Atlantic Salmon, Salmo salar. The tides are approximately $2 \mathrm{~m}$ high in the western basin and seawater is encountered in the estuary where it expands at Campbellton, New Brunswick. More information on Baie des 


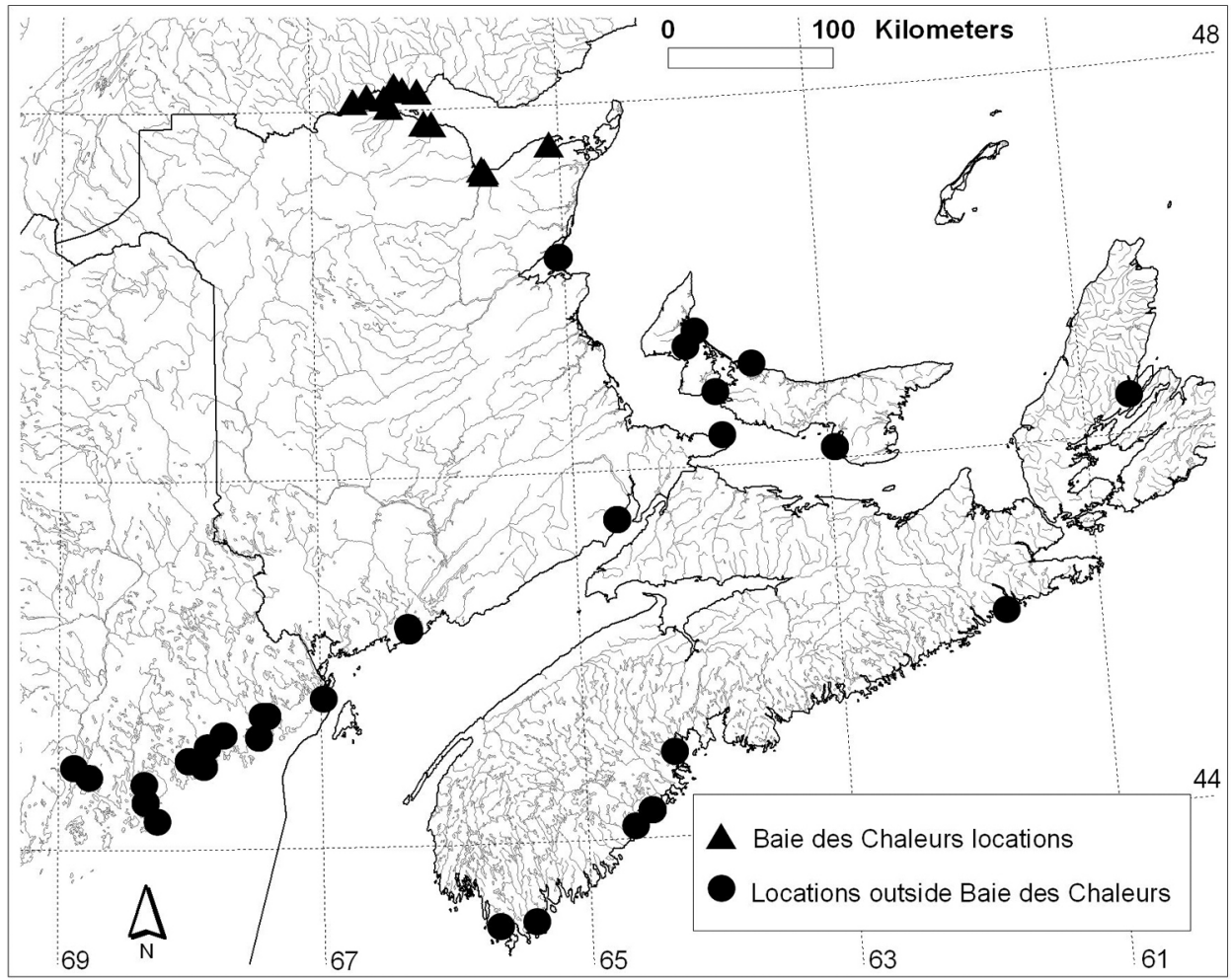

FIGURE 1. Region of Acadia showing saltmarshes visited in Baie des Chaleurs (triangles) and elsewhere (dots).

Chaleurs is available from Gauthier (2005), but there is apparently little information other than this recent reference (National Wetlands Working Group 1988).

\section{Data gathering}

Summarized below for the Baie des Chaleurs region are our late summer and fall observations of dragonflies in saltmarshes as well as some from the Atlantic Dragonfly Inventory Project (ADIP 2007*) for the same region. These observations cover the period from 22 July to 1 October over the past decade. The period of observation at any of these sites was at least 1-2 hours on any particular date. A list of observations at each site is followed by an annotated list of species and additional summary comments. In discussing the observations, the term "frequent" indicates a species seen often (e.g. at many sites) whereas "abundant" refers to a relatively large number of individuals at one or more sites.

All of the sites noted were dominated by plant species considered to be obligate halophytes, including two species of Spartina (S. alterniflora and S. patens), and Ruppia maritima was present in pools at most sites. The presence of these and other obligate halophytes indicates clearly that the sites were saltmarsh- es subject to periodic inflow of saltwater. Voucher specimens for the records of dragonflies for Baie des Chaleurs and elsewhere in Acadia are at the Canadian National Collection at the Agriculture and Agri-food (AAFC) Central Experimental Farm in Ottawa (Canadian National Collection $\mathrm{CNC}$ ), and in the insect collections of the Nova Scotia Museum (NSMNH), the New Brunswick Museum (NFM) and the personal collection of P. M. Brunelle.

\section{Comparisons}

To explore differences between dragonfly occurrence in Baie des Chaleurs and elsewhere on the North Atlantic coast, the number of sites recorded for species of dragonflies in Baie des Chaleurs was compared with similar data (ADIP 2007*) for the rest of Acadia (Canadian Maritime Provinces and the state of Maine) outside of Baie des Chaleurs. Only records for the period from 22 July until the end of October are included in the comparison to represent late summer and autumn use of saltmarshes, and all records are for the past decade. Number of sites where a species was present was expressed as a percentage of total saltmarsh sites visited. The extent to which the Baie des Chaleurs dragonfly fauna is different was explored us- 


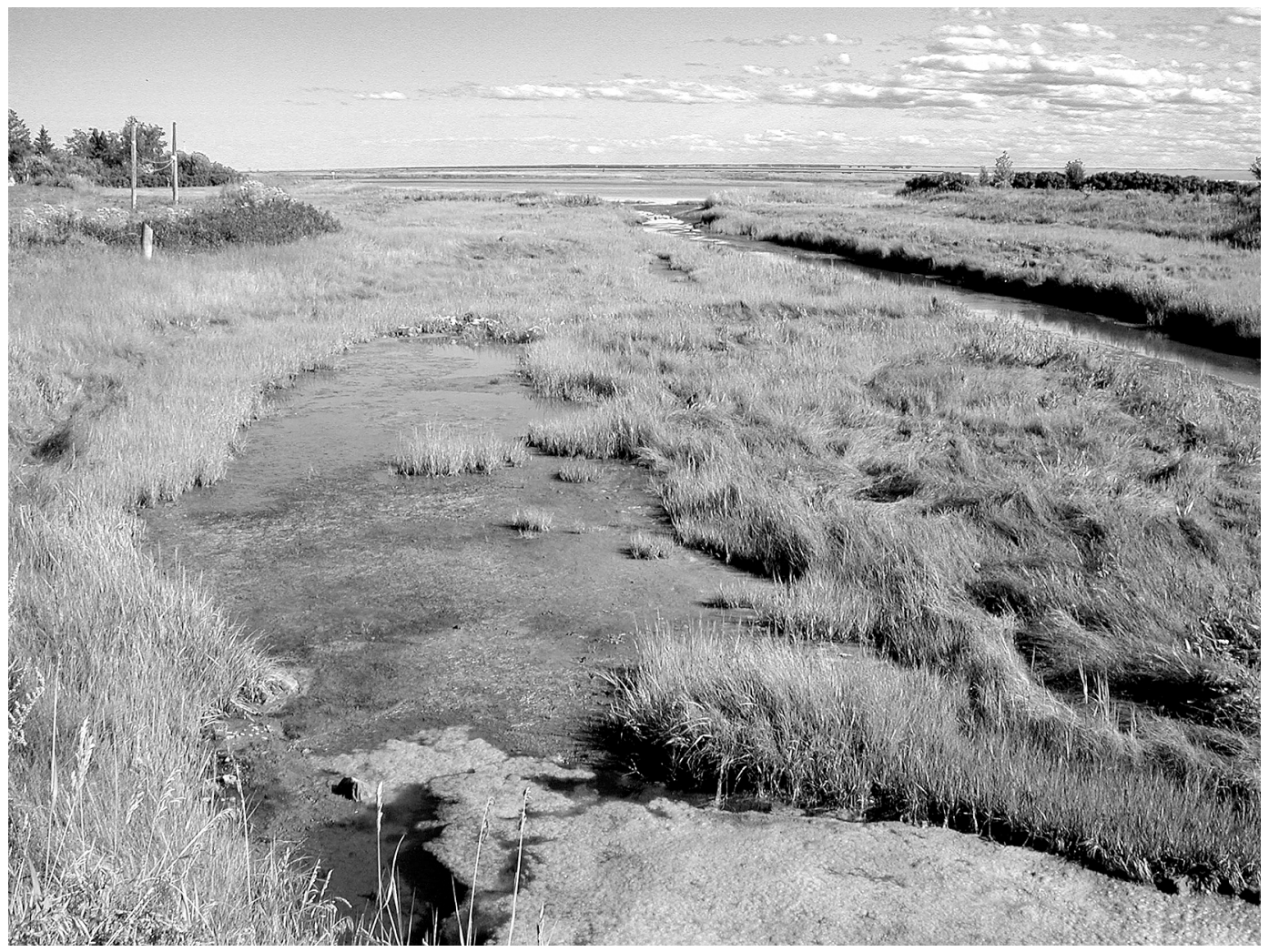

FIGURE 2. Brackish pool in saltmarsh at St. Omer (site 4) where two females of Sympetrum danae were seen ovipositing in the foreground bed of floating algae and Ruppia maritima. The pool is surrounded by Scirpus spp. , Juncus gerardii and Spartina alterniflora. Eight male Sympetrum danae patrolled the edge of this $25 \mathrm{~m}^{2}$ pool, which is inundated by saltwater during high spring and fall tides.

ing a Chi-square test and percentage frequency elsewhere in Acadia to predict percentage frequency in Baie des Chaleurs. The test also allows the comparison of Chi-square values for individual species, but considering the sample size, the values are most useful to identify species contributing substantially to differences between Baie des Chaleurs and elsewhere, rather than to indicate a specific level of significance.

\section{Results}

Sites and species present

For each site, observation dates are given followed by species in alphabetical order and number of individuals seen in brackets. The total for each site and the size and nature of the area surveyed are also given. In cases where we are not the observers, the observers are listed at the end. A total of 18 species of Odonata was encountered in 14 saltmarshes in the Baie des Chaleurs in late summer and autumn.

(1) Bathurst (Queen Elizabeth and Youghall streets), New Brunswick $\left(47.6648^{\circ} \mathrm{N}, 65.6328^{\circ} \mathrm{W}\right), 14$ August 2005: Aeshna canadensis (25), Enallagma hageni (40), Libellula quadrimaculata (2), Somatochlora elongata (4), Sympetrum costiferum (5), S. internum (25), S. vicinum (4). Total: 7 species. Size: The site included a brackish $1 / 2$ acre pool.

(2) $4 \mathrm{~km} \mathrm{E}$ of Pointe-à-la-Croix, Quebec $\left(48.0520^{\circ} \mathrm{N}\right.$, $66.6528^{\circ} \mathrm{W}$ ), 15 August 2005: Aeshna canadensis (30), Lestes congener (4), Lestes disjunctus (2), Sympetrum costiferum (1), S. danae (9), S. internum (200), S. obtrusum (2). Total: 7 species. Size: 50 acres traversed, including creeks, pools and a river.

(3) Pointe-à-la-Garde, Quebec $\left(48.0773^{\circ} \mathrm{N}, 66.5425^{\circ} \mathrm{W}\right), 15$ August 2005: Aeshna canadensis (50), Enallagma hageni (43), Lestes congener (10), L. disjunctus (5), Sympetrum costiferum (1), S. danae (15), S. internum (150). Total: 7 species. Size: 10 acres traversed with many pools and creeks.

(4) Saint-Omer, Quebec $\left(48.1087^{\circ} \mathrm{N}, 66.2514^{\circ} \mathrm{W}\right), 15$ August 2005: Aeshna canadensis (18), Lestes congener (5), L. disjunctus (1), Enallagma hageni (1), Sympetrum danae (15). Total: 5 species. Size: 3 acres with pools beside creek (Figure 2).

(5) Charlo, New Brunswick $\left(48.0182^{\circ} \mathrm{N}, 66.3666^{\circ} \mathrm{W}\right), 16$ August 2005: Aeshna canadensis (1), Lestes congener (3), Sympetrum danae (1), Sympetrum internum (2). Total: 4 species. Size: $1 / 2$ acre with one small pool.

(6) Nash Creek, New Brunswick $\left(47.9229^{\circ} \mathrm{N}, 66.0840^{\circ} \mathrm{W}\right)$, 16 August 2005: Aeshna canadensis (6), Sympetrum danae 
TABLE 1. Locations of saltmarshes visited in Baie des Chaleurs and elsewhere in Acadia over the past ten years within the period 22 July to 1 October. The order is increasing latitude from left to right and top to bottom.

Baie des Chaleurs

$47.6648,65.6328$

$48.0182,66.3666$

$48.1000,66.1348$

$47.64,65.62$

\author{
$48.0520,66.6528$ \\ $47.9229,66.0840$ \\ $48.0500,65.4833$ \\ $47.65,65.61$
}

$48.0773,66.5425$
$47.9166,66.0241$
$48.1333,66.3166$
$48.1087,66.2514$

$47.0657,65.0750$

47.7846, 65.0841

Acadia outside Baie des Chaleurs

43.5694, 65.4139

$44.15,68.25$

$44.3889,68.7667$

$44.479,68.013$

$44.7194,67.45$

$45.1699,66.3135$

$46.1635,63.8258$

46.6532, 64.0748
43.5702, 65.3747

$44.2518,68.3398$

$44.4417,68.8833$

$44.5556,67.8722$

$44.72,67.41$

$45.19,66.32$

$46.2083,60.6333$

46.732, 63.9946
44.0667, 64.6417

$44.2535,68.3406$

$44.45,67.9$

44.605, 67.48

$44.8111,66.9806$

$45.7321,64.6765$

$46.4,63.86$

$47.1667,65.0493$
$44.1483,64.5106$

$44.35,68.35$

$44.4587,64.3215$

44.6194, 67.7472

$45.107,61.7266$

$46.06,62.95$

$46.5403,63.56$

$47.1721,65.0372$
(1), S. internum (4), S. obtrusum (1). Total: 4 species. Size: 5 acres with pools and creeks.

(7) Jacquet River Marsh, New Brunswick $\left(47.9166^{\circ} \mathrm{N}\right.$, 66.0241 ${ }^{\circ} \mathrm{W}$ ), 16 August 2005: Aeshna canadensis (30 adults 1 larva probably this species), Aeshna umbrosa (1 larva probably this species), Lestes congener (50), L. disjunctus (1), Ischnura verticalis (200 adults, 4 larvae), Sympetrum danae (1), S. internum (5). Total: 7 species. Size: traversed 10 acres with pools and creeks.

(8) North of Eel River, New Brunswick $\left(48.0657^{\circ} \mathrm{N}\right.$, 66.4000 $\left.{ }^{\circ} \mathrm{W}\right), 16$ August 2005: Aeshna canadensis (22), A. interrupta (3), Enallagma civile (26), Enallagma hageni (1), E. ebrium (1), Ischnura verticalis (100), Lestes congener (10), L. disjunctus (4), L. forcipatus (2), Sympetrum internum (70), S. obtrusum (40). Total: 11 species. Size: at least 50 acres traversed with numerous creeks and pools, all brackish, at least periodically.

(9) Carleton, Quebec $\left(48.1000^{\circ} \mathrm{N}, 66.1348^{\circ} \mathrm{W}\right), 29$ September-1 October 2004: Aeshna umbrosa (5+), Enallagma civile (3), Sympetrum danae (7), S. internum (1), S. vicinum (1); S. costiferum (1); 10 September 1999, Enallagma civile (2), Sympetrum danae (4); 4 September 1995, Sympetrum danae (3), Sympetrum sp. (1 reddish specimen). Total: 6 species. Size: pools within an area of 3 acres.

(10) Bonaventure, Quebec $\left(48.0500^{\circ} \mathrm{N}, 65.4833^{\circ} \mathrm{W}\right), 3$ September 1995: Aeshna sp. (2), Pantala flavescens (1), Sympetrum costiferum (1), S. danae (10). Total: 4 species. Size: 3 acres.

(11) Nouvelle (saltmarsh of the Nouvelle River Basin), Quebec $\left(48.1333^{\circ} \mathrm{N}, 66.3166^{\circ} \mathrm{W}\right), 4$ September 1995: Lestes congener (1), Sympetrum danae (1), Sympetrum sp. (1, reddish). Total 3 species.

(12) Caraquet Bay, New Brunswick $\left(47.7846^{\circ} \mathrm{N}, 65.0841^{\circ} \mathrm{W}\right)$ saltmarsh, 12 August 2002: Sympetrum danae (3), Sympetrum internum (1), Sympetrum obtrusum (1). Observer: Dwayne L. Sabine. Total: 3 species.

(13) Daly Point Marsh, Bathurst Harbour, New Brunswick $\left(47.64^{\circ} \mathrm{N}, 65.62^{\circ} \mathrm{W}\right), 12$ August 1993: Sympetrum danae (1). Observer: Reginald P. Webster. 21 July 1999, Libellula quadrimaculata (2), Aeshna canadensis (2). Total 3 species.

(14) Carron Point Marsh, Bathurst Harbour, New Brunswick $\left(47.65^{\circ} \mathrm{N}, 65.61^{\circ} \mathrm{W}\right), 22$ July 1999: Aeshna canadensis (1),
Libellula quadrimaculata, Sympetrum danae (2), Sympetrum obtrusum (1). Total: 4 species.

Annotated List of Species (alphabetical order) Aeshna canadensis: at 10 sites and frequent at some, apparently uses saltmarsh regularly as an adult hunting on salty pools of the outer marshes which are influenced by tides regularly, as well as inner brackish pools; seen to oviposit in saltmarsh pools. A larva $20 \mathrm{~mm}$ long that was probably (but not definitely, due to difficulty of identifying young larvae) referable to this species was retrieved from a periodically brackish pool dominated by Ruppia maritima (site 7).

Aeshna interrupta lineata: only one at one site but of interest because this subspecies exists at low frequencies in the Atlantic provinces and is largely confined to the Gulf of St. Lawrence area. The specimen was referred to subspecies lineata on the basis of uninterrupted lateral stripes. This species is reported to tolerate saline waters (Dunkle 2000).

Aeshna umbrosa: only from two sites but five adults seen patrolling saltmarsh ponds; at the other site two young larvae probably referable to this species ( 21 and $23 \mathrm{~mm}$ long) were found in a brackish pool dominated by Ruppia maritima (site 7) - due to their small size, identification is tentative; mature larvae of this species were found in water-filled pockets within the storm splash zone of a sea cliff near Port-auSaumon, Quebec (Hutchinson 1999); and D. Sabine (personal communication) found larvae in a small depression pool in a seaside boulder within the tidal splash zone on the Fundy shore of New Brunswick.

Enallagma civile: two sites; twenty-six captured (most released), many paired, were flying over a periodically brackish creek in saltmarsh with mostly Ruppia maritima, also Zannichellia palustris, Potamogeton pectinatus, lined by Spartina alterniflora ( site 8). Enallagma civile was first reported from this region by Hutchinson and Bélanger (2004), and their report was from a saltmarsh habitat at Carleton (site 9), where they observed oviposition behaviour (but did not actually see eggs). Osborn (1906) reported a tolerance of brackish water.

Enallagma ebrium: only one at one site, so likely vagrant.

Enallagma hageni: At four sites and abundant at two; 40 seen and several ovipositing on Ruppia maritima around a brackish, $1 / 2$ acre pool with dense beds of Ruppia maritima surrounded by Spartina alterniflora, S. patens, S. pectinata, and Carex 
TABLE 2. Comparison of species of dragonflies recorded from Acadia outside of Baie des Chaleurs and Baie des Chaleurs based on number (left) and percentage (right) of total saltmarsh sites visited. Acadia includes the Maritime Provinces (Nova Scotia, New Brunswick and Prince Edward Island) of Canada and the state of Maine. Records from Acadia are from the ADIP database (2007). Records from Baie des Chaleurs are those reported here and are also in ADIP 2007. Only records for the period from 22 July until the end of October are included in the comparison to represent late summer and autumn use of saltmarshes. Chi-square values for each species based on comparison of frequency elsewhere in Acadia to predict frequency in Baie des Chaleurs are included to highlight species most different in their occurrence in these two regions in bold. Names are taken from Catling et al. (2005).

\begin{tabular}{|c|c|c|c|c|c|}
\hline \multirow{2}{*}{$\begin{array}{l}\text { Species } \\
\text { Lestes congener Hagen, Spotted Spreadwing }\end{array}$} & \multicolumn{2}{|c|}{$\begin{array}{c}\text { Acadia } \\
\mathrm{n}=32\end{array}$} & \multicolumn{2}{|c|}{$\begin{array}{c}\text { Chaleurs } \\
\mathrm{n}=14\end{array}$} & \multirow{2}{*}{$\begin{array}{r}\text { Chi-square } \\
\mathbf{3 5 2 . 8 8 7 2}\end{array}$} \\
\hline & 1 & 3.1 & 7 & 50.0 & \\
\hline Lestes disjunctus Sélys, Northern Spreadwing & 5 & 15.6 & 5 & 35.7 & 21.4439 \\
\hline Lestes forcipatus Rambur, Sweetflag Spreadwing & 1 & 3.1 & 1 & 7.1 & 2.6130 \\
\hline Lestes inaequalis Walsh, Elegant Spreadwing & 1 & 3.1 & - & - & 1.5500 \\
\hline Lestes rectangularis Say, Slender Spreadwing & 4 & 12.5 & - & - & 10.0160 \\
\hline Lestes unguiculatus Hagen, Lyre-tipped Spreadwing & 2 & 6.2 & - & - & 4.1333 \\
\hline Enallagma aspersum (Hagen), Azure Bluet & 1 & 3.1 & - & - & 1.5500 \\
\hline Enallagma civile (Hagen), Familiar Bluet & 8 & 25.0 & 2 & 14.3 & 4.1125 \\
\hline Enallagma durum (Hagen), Big Bluet & 1 & 3.1 & - & - & 1.5500 \\
\hline Enallagma ebrium (Hagen), Marsh Bluet & 2 & 6.2 & 1 & 7.1 & 0.0920 \\
\hline Enallagma hageni (Walsh), Hagen's Bluet & 10 & 31.2 & 4 & 28.6 & 0.2125 \\
\hline Ischnura verticalis (Say), Eastern Forktail & 6 & 18.7 & 2 & 14.3 & 0.9084 \\
\hline Aeshna canadensis Walker, Canada Darner & 7 & 21.8 & 10 & 71.4 & 98.2049 \\
\hline Aeshna constricta Say, Lance-tipped Darner & 3 & 9.3 & - & - & 6.9759 \\
\hline Aeshna eremita Scudder, Lake Darner & 2 & 6.3 & - & - & 4.2223 \\
\hline Aeshna interrupta Walker, Variable Darner & 5 & 15.6 & 1 & 7.1 & 3.8409 \\
\hline Aeshna umbrosa umbrosa Walker 1908, Shadow Darner & 4 & 12.5 & 2 & 14.3 & 0.1963 \\
\hline Anax junius (Drury), Common Green Darner & 1 & 3.1 & - & - & 1.5500 \\
\hline Dorocordulia lepida (Hagen in Sélys), Petite Emerald & 2 & 6.2 & - & - & 4.1333 \\
\hline Somatochlora elongata (Scudder), Ski-tipped Emerald & 3 & 9.3 & 1 & 7.1 & 0.3815 \\
\hline Somatochlora kennedyi Walker, Kennedy’s Emerald & 1 & 3.1 & - & - & 1.5500 \\
\hline Celithemis elisa (Hagen), Calico Pennant & 1 & 3.1 & - & - & 1.5500 \\
\hline Erythrodiplax berenice (Drury), Seaside Dragonlet & 8 & 25.0 & - & - & 22.2420 \\
\hline Leucorrhinia frigida Hagen, Frosted Whiteface & 1 & 3.1 & - & - & 1.5500 \\
\hline Libellula luctuosa Burmeister, Widow Skimmer & 1 & 3.1 & - & - & 1.5500 \\
\hline Libellula pulchella Drury, Twelve-spotted Skimmer & 2 & 6.2 & - & - & 4.1333 \\
\hline Libellula quadrimaculata Linnaeus, Four-spotted Skimmer & 9 & 28.1 & 3 & 21.4 & 1.4495 \\
\hline Pantala flavescens (Fabricius), Wandering Glider & 3 & 9.3 & 1 & 7.1 & 0.3815 \\
\hline Plathemis lydia (Drury), Common Whitetail & 2 & 6.2 & - & - & 4.1333 \\
\hline Sympetrum costiferum (Hagen), Saffron-winged Meadowhawk & 3 & 9.3 & 5 & 35.7 & $\mathbf{5 5 . 8 8 7 6}$ \\
\hline Sympetrum danae (Sulzer), Black Meadowhawk & 5 & 15.6 & 12 & 85.7 & 261.2840 \\
\hline Sympetrum internum Montgomery, Cherry-faced Meadowhawk & 12 & 37.5 & 9 & 64.3 & 17.4604 \\
\hline Sympetrum obtrusum (Hagen), White-faced Meadowhawk & 9 & 28.1 & 5 & 35.7 & 1.8149 \\
\hline Sympetrum semicinctum (Say), Band-winged Meadowhawk & 5 & 15.6 & - & - & 13.0139 \\
\hline Sympetrum vicinum (Hagen), Autumn Meadowhawk & 2 & 6.2 & - & - & 4.1333 \\
\hline
\end{tabular}

paleacea, flooded by high tides in fall according to local residents (site 1); 43 around pools and creeks with Ruppia maritima, Zannichellia palustris, Potamogeton pectinatus and Enteromorpha sp. (site 3).

Ischnura verticalis: abundant at each of two locations; more than 200 seen around pools with Potamogeton pectinatus and Ruppia maritima with Spartina pectinata fringe, some ovipositing, and at the the same location four larvae $17-21 \mathrm{~mm}$ long referable to this species were collected from the pools (site 7); more than 100 were seen around spring-fed pools surrounded by Spartina pectinata, Spartina alterniflora, Spartina patens and species of Scirpus (site 8). In both cases the pools were fed by freshwater springs but were definitely subject to saltwater during high tides.

Lestes congener: at seven sites and at least 82 individuals overall; given the number of sites and the number of individ- uals this species may be a resident of saltmarsh; several pairs seen ovipositing on Juncus balticus and Juncus gerardii around brackish pools with Potamogeton pectinatus and Ruppia maritima (site 7).

Lestes disjunctus: at five sites; but not as abundant as $L$. congener.

Lestes forcipatus: only one at one location.

Libellula quadrimaculata: at three sites; adults patrolled a brackish pool at site 1; said to tolerate saline waters (Dunkle 2000).

Pantala flavescens: only one at one location and probably a migrant.

Somatochlora elongata: only found at one location, but four seen over pool with Ruppia maritima surrounded by Spartina alterniflora, S. patens, S. pectinata, and Carex paleacea, flood- 
ed by high tides in fall according to local residents (site 1). This species has also been reported from four other saltmarshes in Acadia (Table 2).

Sympetrum danae: at 12 sites, and abundant on the north side of the bay, patrolling saltmarsh pools very much like Erythrodiplax berenice does in saltmarshes further south on the Atlantic coast. Two females were seen ovipositing in a pool $25 \mathrm{~m}^{2}$ with a thick bed of Ruppia maritima surrounded by Scirpus spp., Juncus gerardii and Spartina alterniflora (site 4 , Figure 2). The pool was said by local people to be flooded by high tides in spring and fall. Ovipositing behaviour was also observed in saltmarsh ponds at Carleton but eggs were not actually seen. The species appears to be less frequent in the saltmarshes on the south side of the bay. Hutchinson and Bélanger (2004) have previously drawn attention to the utilization of saltmarsh by adults of this species and suggested the possibility that larvae may mature in brackish pools. High salinity of spring and fall high tides may be avoided by the resistant egg stage that overwinters. Larval development may be relatively rapid (Corbet 1999) and allow use of saltmarsh pools during periods of minimal tidal impact. Although the larval habitat of this species is widely reported in both Europe and North America as oligotrophic pools and small lakes on bogs and heathlands, it also inhabits very alkaline fens in eastern and northern Canada. Consequently saltmarsh pools would not be so remarkable a habitat. Interestingly in Ireland, males are said to be non-territorial (Nelson and Thompson 2000*), contrary to some of our observations on saltmarsh pools. In some places within its holarctic range, $S$. danae is reported to migrate (e.g. Corbet 1999, page 420). Ability to utilize brackish habitats may be beneficial to migrants over water in the maritime regions where landfall may have only brackish habitat.

Sympetrum internum: at nine sites and abundant at some. One emerging from a pool surrounded by Spartina pectinata in upper marsh (site 2) and tenerals in several sites; uses saltmarsh extensively as an adult and the upper marsh at least to some extent as larval habitat.

Sympetrum costiferum: at five sites; two emerging from brackish $1 / 2$ acre pool with dense beds of Ruppia maritima surrounded by Spartina alterniflora, S. patens, $S$. pectinata and Carex paleacea, flooded by high tides in fall according to local residents (site 1); one emerging from sandy bottom creek with Ruppia maritima and Enteromorpha sp. (site 3). Apparently uses saltmarsh habitats for development but in low numbers, possibly due to limited amount of sandy larval habitat in most marshes. According to Walker and Corbet (1975), S. costiferum appears to be more tolerant of saline waters than other species of Sympetrum, but they are not clearly referring to sodium salts. Dunkle (2000) also refers to tolerance of saline waters.

Sympetrum obtrusum: at five sites but no strong evidence of use of saltmarsh as larval habitat by this widespread and generally abundant species.

Sympetrum vicinum: at two locations but at one of these two were emerging from brackish $1 / 2$ acre pool with dense beds of Ruppia maritima surrounded by Spartina alterniflora, $S$. patens and $S$. pectinata, and Carex paleacea, flooded by high tides in fall according to local residents (site 1).

\section{Discussion}

Comparison with saltmarshes elsewhere in Acadia

A total of 35 species has been recorded from saltmarshes in Acadia (Table 2). Several occurred in relatively high frequencies in both Baie des Chaleurs saltmarshes and saltmarshes elsewhere in Acadia suggesting some degree of salinity tolerance. Included in this category are Aeshna canadensis, A. umbrosa, Enallagma civile, E. hageni, Ischnura verticalis, Lestes disjunctus, Libellula quadrimaculata, Sympetrum danae, S. internum and S. obtrusum.

With a Chi-square value of 912.707, the saltmarsh dragonfly fauna of Baie des Chaleurs is significantly (well below the 0.005 level) different from that of the rest of Acadia based on frequencies predicted from the latter region. Based on Chi-square values exceeding 10.0 (significance below the 0.005 level), Baie des Chaleurs saltmarshes differed from sites elsewhere in having significantly more sites for six generally widespread species that occur throughout Acadia (Table 2, Donnelly 2004a, b, c) including Lestes congener, Sympetrum danae, Aeshna canadensis, Sympetrum costiferum, Lestes disjunctus, and Sympetrum internum (in order of decreasing significance). Three species were significantly less frequent in Baie des Chaleurs including Erythrodiplax berenice, Sympetrum semicinctum, and Lestes rectangularis all of which do not extend as far north as Baie des Chaleurs (Donnelly 2004b, c). Erythrodiplax berenice for example does not occur north of $45^{\circ} \mathrm{N}$, whereas Baie des Chaleurs is situated at $48^{\circ} \mathrm{N}$.

\section{General Observations}

With 35 species of adult dragonflies recorded in saltmarshes in Acadia and 18 in Baie des Chaleurs, and in both cases, approximately half of them occurring in more than $15 \%$ of sites, substantial use by dragonflies is suggested. This is further supported by records of emergence, presence of larvae, ovipositing behaviour and relatively large numbers of individuals.

In a number of saltmarsh habitats further south on the coast of New England, the only abundant dragonfly species that we have observed using the saltmarsh habitat in late summer is the saltmarsh specialist, Erythrodiplax berenice. It is often present in large numbers (to 30 per acre), the males patrolling pools, the females along the marsh edges but pairs frequent over the marsh in early to mid-morning. Other Odonatists have also noted that in many saltmarshes the only dragonfly present is E. berenice (D. Paulson, personal communication). Other species fly over the marshes including the migratory Anax junius, Tramea spp., and Pantala spp. All of these may hunt over the marsh but seem much more often to hunt and congregate in open shrubby areas around the marsh edge. We have seen species of Enallagma, Lestes and Sympetrum only occasionally in these more southern saltmarshes. There may be a trend toward more extensive use of saltmarsh by dragonflies in a northerly direction. Possibly saltmarshes further south are less utilized by widespread dragonfly species because salt may be more concentrated in pools of upper marsh due to higher evaporation. 


\section{Baie des Chaleurs}

The fact that Baie des Chaleurs saltmarshes differed from sites elsewhere in Acadia in having very significantly more sites for six generally widespread species, including Lestes congener, Sympetrum danae, Aeshna canadensis, Sympetrum costiferum, Lestes disjunctus, and Sympetrum internum (in order of decreasing significance), suggests either that there has been some adaptation to saltmarsh conditions by these wideranging species in this region, or that saltmarshes in this region are more readily colonized as a result of unique characteristics, or both. Baie des Chaleurs is home to an endemic and endangered saltmarsh butterfly, the Maritime Ringlet (Coenonypha tullia nipisiquit, McDunnough 1939). Recent studies have suggested that this butterfly has evolved physiological adaptation to saline wetland conditions including tolerance of tidewater submergence for up to 24 hours (Webster 1998; Sei 2004). The endemic but somewhat more widespread Maritime Copper Butterfly (Lycaena dospassosi McDunnough) is also confined to the saltmarshes of northern New Brunswick and Gaspé (Thomas 1980).

Unique charaterisitics of Baie des Chaleurs saltmarshes may be widespread or local, or both. Parts of saltmarsh are prohibitively salty for non-adapted species only during high tides in the spring and fall, and even then saltwater may be somewhat diluted due to the estuary effect. There are distinctive east and west basins and in the west basin, where most of our observations were made and where the Maritime Ringlet occurs, the tides are higher and salt concentrations lower than in the east basin (Gauthier 2005). It has been suggested that saltmarshes can be divided into two kinds, estuarine such as Baie des Chaleurs, and coastal (National Wetlands Working Group 1988). Although the difference between the two types is not perfectly clear, conditions of inundation and salt concentrations in coastal saltmarsh would be more severe.

Saltmarshes have periodic inundation in common, but the timing and duration may vary as well as the salt concentrations. Furthermore, occasional lack of ice development in the bay may result in severe impact of high tide associated with winter storms on some saltmarshes, while others may be protected by barrier beaches (Webster 1994*, 1998). Local amelioration of salty conditions in certain saltmarshes, superimposed on regional amelioration, may provide an environment where tolerant species can exist and adaptation can occur.

\section{Tolerance of salt}

Although the places where dragonflies were recorded in Baie des Chaleurs saltmarshes may not have been consistently high in salt concentration, they were definitely brackish, were part of a tidal salt marsh subject to periodic inundation with salt water and subject to salt to the extent of excluding non-halophytic flora. Species of dragonflies differ in their ability to cope with salt (Cannings and Cannings 1987). Of the 18 species found in Baie des Chaleurs, Aeshna interrupta, Libellula quadrimaculata, Sympetrum danae, and S. costiferum are reported by Dunkle (2000) to tolerate saline water. However, Walker $(1953,1958)$, Walker and Corbet (1975), Pilon and Lagacé (1998) do not report any of the species listed here as occurring in saltmarsh. Observations in Baie des Chaleurs suggest that dragonflies occupy saltmarshes to a greater extent than is currently documented. Ecological and evolutionary aspects, including extent to which local adaptation has occurred, require more study, particularly directed toward larval occurrences and comparisons with other habitats in the surrounding landscape.

\section{Acknowledgments}

Brenda Kostiuk and Gilbert Bélanger assisted with field work. Reginald P. Webster and Dwayne L. Sabine contributed information to the Atlantic Dragonfly Inventory Project, which was used here for comparison with Baie des Chaleurs. Robert Anderson of the Canadian Museum of Nature provided helpful comments.

\section{Documents Cited}

Atlantic Dragonfly Inventory Program (ADIP). 2007. Database maintained by Paul M. Brunelle, Nova Scotia Museum, Halifax (searched March 2007).

Nelson, B., and R. Thompson. 2000. The natural history of Ireland's dragonflies. www.habitas.org.uk/dragonflyireland/ 5651d.htm.

Webster, R. P. 1994. The life history and ecology of the Maritime Ringlet butterfly, Coenonympha inornata nipisiquit McDunnough. Report for the Endangered Species Recovery Fund, World Wildlife Fund Canada and the New Brunswick Department of Natural Resources and Energy, Fish and Wildlife Branch. 18 pages

\section{Literature Cited}

Cannings, R. A., and S. G. Cannings. 1987. The Odonata of some saline lakes in British Columbia, Canada: ecological distribution and zoogeography. Advances in Odonatology 3: 7-21.

Catling, P. M., R. A. Cannings, and P. Brunelle. 2005. An annotated checklist of the Odonata of Canada. Bulletin of American Odonatology 9(1): 1-20.

Cheng, L., Editor. 1976. Marine insects. Elsevier Publishing Co., New York. 581 pages.

Corbet, P. S. 1999. Dragonflies, behaviour and ecology of the Odonata. Cornell University Press, Ithaca, New York. 829 pages.

Donnelly, T. W. 2004a. Distribution of North American Odonata. Part I: Aeshnidae, Petaluridae, Gomphidae, Cordulegastridae. Bulletin of American Odonatology 7(4): 6190.

Donnelly, T. W. 2004b. Distribution of North American Odonata. Part II: Macromiidae, Corduliidae and Libellulidae. Bulletin of American Odonatology 8(1): 1-32.

Donnelly, T. W. 2004c. Distribution of North American Odonata. Part III: Calopterygidae, Lestidae, Coenagrionidae, Protoneuridae, Platystictidae with data sources and bibliography, parts I-III. Bulletin of American Odonatology 8(2-3): 33-99. 
Dunkle, S. 2000. Dragonflies through binoculars. Oxford University Press. 266 pages.

Foster, W. A., and J. E. Treherne. 1976. Insects of marine saltmarshes, problems and adaptations. Pages 5-42 in Marine insects. Edited by L. Cheng. Elsevier Publishing Co., New York.

Gauthier, B. 2005. L'estuaire de la baie des Chaleurs Réstigouche. Le Naturaliste canadien 129(2): 51-56.

Hutchinson, R. 1999. Aeshna umbrosa larvae found in extremely shallow water. Argia 2(2): 7.

Hutchinson, R., and G. Bélanger. 1999. Découverte d'Enallagma civile (Hagen) (Odonata: Coenagrionidae) dans la baie des Chaleurs en Gaspésie (Québec). Fabreries 24(4): $82-84$.

Hutchinson, R., and G. Bélanger. 2004. Le marais salé comme habitat potentiel pour Sympetrum danae (Sulzer) (Odonata: Libellulidae). Fabreries 29(1): 16.

McDunnough, J. 1939. A new Coenonympha race from northeast New Brunswick. Canadian Entomologist 71: 266.

National Wetlands Working Group. 1988. Wetlands of Canada. Canadian Wildlife Service, Ecological Land Classification Series 24. 452 pages.

Osborn, R. C. 1906. Observations and experiments on dragonflies in brackish water. American Naturalist 40: 395-399.
Pilon, J.-G., and Lagacé. 1998. Les odonates du Québec. Entomofaune du Québec. Chicoutimi. 367 pages.

Sei, M. 2004. Larval adaptation of the Endangered Maritime Ringlet (Coenonympha tullia nipisiquit McDunnough (Lepidoptera: Nymphalidae) to a saline wetland habitat. Environmental Entomology 33(6): 1535-1540.

Thomas, A. W. 1980. New locality records for the salt marsh copper, Epidemia dorcas dospassosi (Lycaenidae). Journal of the Lepidopterists' Society 34: 315.

Walker, E. M. 1953. The Odonata of Canada and Alaska. Volume 1. University Toronto Press, Toronto. 292.

Walker, E. M. 1958. The Odonata of Canada and Alaska. Volume 2. University Toronto Press, Toronto. 318 pages.

Walker, E. M., and P. S. Corbet. 1975. The Odonata of Canada and Alaska. Volume 3. University of Toronto Press. 307 pages.

Webster, R. P. 1998. The life history of the maritime ringlet, Coenonympha tullia nipisiquit (Satyridae). Journal of the Lepidopterist's Society 52(4): 345-355.

Received 30 November 2005

Accepted 29 March 2007 